\title{
Corrosion Behavior of Some Timonb Alloys in Ringer Solution
}

\author{
MARIA MAGDALENA PRICOPI ${ }^{1}$, ROMEU CHELARIU ${ }^{2}$, NICOLAE APOSTOLESCU ${ }^{1}$, \\ DOINA-MARGARETA GORDIN ${ }^{3}$, DANIEL SUTIMAN ${ }^{1}$, DANIEL MARECI ${ }^{1}$
}

\author{
1"Gheorghe Asachi" Technical University of Iasi-Romania, Faculty of Chemical Engineering and Environmental Protection \\ 73 Mangeron Blvd., 700050, Iasi, Romania \\ 2"Gheorghe Asachi" Technical University of Iasi-Romania, Faculty of Materials Science and Engineering, 41 Mangeron \\ Blvd., 700050, Iasi, Romania \\ ${ }^{3}$ Univ Rennes, INSA Rennes, CNRS, ISCR (Institut des Sciences Chimiques de Rennes), F-35000 Rennes, France.
}

\begin{abstract}
The aim of this study was to investigate the influence of different process parameters as chemical composition, the $\mathrm{pH}$ value and immersion time on the corrosion of the some TiMoNb alloys, using different electrochemical techniques such as: cyclic voltammetry, open circuit potential (OCP) measurement, polarization curves and electrochemical impedance spectroscopy (EIS). The alloys were analyzed in the natural pH of the Ringer solution, but also with an acidic modification of the solution $(p h=4)$ and a basic modification $(p h=8)$. The more acidic values of $p H$, the more evident are differences between corrosion behavior of titanium-based alloys depending on their chemical compositions and immersion times.
\end{abstract}

Keywords Ti-Nb-Mo alloys, Ringer solution, corrosion

\section{Introduction}

Titanium and its alloys are intensively studied in dental medicine due to their excellent biocompatibility, corrosion resistance and relatively low density [1]. Attempts to use titanium in the manufacture of implants date from the 1930 [2].

Metals such as $\mathrm{Zr}$, Mo, Ni, $\mathrm{Nb}$, Ta are elements that may be present in titanium alloys, as they exhibit excellent biocompatibility and belong to the group of non-toxic metals in their interaction with living tissue. Also, these elements are the most suitable alloying elements that can be added to decrease the modulus of elasticity without compromising its mechanical resistance [3-4]. In the case of titanium alloys, different methods of improving the corrosion resistance have been studied [5]. As an alloying element, niobium is known to be particularly for corrosion resistance in the simulated body fluid, also presenting a particularly good biocompatibility [6-7]. The use of molybdenum is still controversial, but some studies have shown that some Mo-containing $\mathrm{Ti}$ alloys can have adequate mechanical compatibility and good cytotoxic compatibility such as Ti-Mo, Ti-Mo-Ta, Ti-Mo-Zr-Fe [813]. The advantage of Mo is that it is a strong stabilizer of the $\beta$ phase for Ti alloys in comparison to $\mathrm{Nb}$, Ta or $\mathrm{Zr}$ [14-15]. Titanium alloys have been studied in different physiological mediums, such as artificial saliva, Hank solution, Ringer solution, $\mathrm{NaCl}$ solution to understand their electrochemical behavior as biomaterials subjected to corrosion in human organism [16-20]. In some studies, the influence of molybdenum content on corrosion resistance of Ti-Mo alloys in different simulated physiological environments has been investigated and one showed that the electrochemical behavior was improved due to the presence of molybdenum [21-26]. The superior properties of Ti-Nb and Ti$\mathrm{Nb}-\mathrm{Zr}$ systems are ascribed to addition of niobium $(\mathrm{Nb})$ as the primary alloying element since it possesses distinguish attributes of improved $\beta$ stability, low elastic modulus and high corrosion resistance [27-36].

\footnotetext{
*email: sutiman@ch.tuiasi.ro
} 
A recent concern of researchers is to find ways to optimize the properties of these alloys with applications in medicine. Thus, efforts are made to find an optimal surface properties of alloys that meets excellent qualities due to which the lifetime of the alloys can be improved in the aggressive environment of the human organism. Ti-based alloys remain some of the most widely used biomaterials. These studies described above were conducted to better understand the electrochemical behavior and their possible effects on the human environment.

The purpose of this study is to highlight the influence of different process parameters, such as $\mathrm{pH}$ of the electrochemical medium, chemical composition of alloys, immersion time on the corrosion behavior of investigated alloys.

\section{Materials and methods}

Samples from 5 alloys were used in this study, symbolized as follows: Ti12Mo, Ti10Mo8Nb, Ti8Mo16Nb, Ti6Mo24Nb and Ti4Mo32Nb. These alloys were synthetized in the specialized laboratory of the ISCR/C-Met-Site INSA Rennes (France) using the induction levitation-melting processing [37].

From as-cast Ti alloys mini-ingots, samples for electrochemical tests having an active area of 0,28 $\mathrm{cm}^{2}$ were prepared by machining, polishing and mirror-like polishing. Before each test, the electrochemical surface of the alloys was sanded with SiC 1000, 2000, and 4000 grains of paper, then rinsed with distilled water and placed in the ultrasonic bath.

The electrochemical tests were performed at room temperature using the Ringer solution (1L solution of Ringer solution: Sodium chloride $8.60 \mathrm{~g}$, Potassium chloride $0.30 \mathrm{~g}$, Calcium chloride dihydrate 0.33 g. $)$ at the natural $p \mathrm{H}(p \mathrm{H}=6.5)$, then Ringer solution at basic $p \mathrm{H}(p \mathrm{H}=8)$ and acidic $\mathrm{pH}$ $(p \mathrm{H}=4) . \mathrm{HCl}$ and $\mathrm{NaOH}$ were used to modify the $\mathrm{pH}$ of initial Ringer solution.

To conduct the electrochemical tests, a glass electrochemical cell was used, with a simple wall and a potentiostatic assembly consisting of a working electrode, a reference electrode (SCE) and a platinum auxiliary electrode. The potentiostat used was PGZ-301. The experimental data was processed with the Voltamaster 4 software. EIS data processing (electrochemical impedance spectroscopy) was performed using the Zsimwiew program.

The tests were performed by scanning the potential with scan rate of $10 \mathrm{mV} / \mathrm{s}$, the applied potential being between $-500 \div 2000 \mathrm{mV}$. Tafel analysis was applied to extract the $\mathrm{E}_{\text {corr }}$ corrosion potential and the corrosion current density jorr.

EIS spectra were recorded for the frequency range between $100 \mathrm{kHz}$ and $25 \mathrm{mHz}$, with a potential amplitude of $10 \mathrm{mV}$ and 20 points per decade.

\section{Results and discussions}

Titanium and its alloys are passive metallic materials in aqueous media. On the surface of bodies from titanium-based metallic materials is spontaneously formed an oxide film characterized by compactness, adherence at substrate and thinness. In contact with aqueous media the features of oxide film changes because thermodynamic and kinetic conditions are changed. The corrosion behavior of titanium-based metallic materials in aqueous electrolytes, and therefore also in natural or simulated biological environments, is depending to passive state for the given conditions.

Using electrochemical methods, the corrosion behavior of some alloys from the Ti-Mo-Nb system in Ringer solution was investigated, thus the use potential of these alloys as biomaterials being preliminary evaluated. The results of the electrochemical tests highlighted the relationship between corrosion parameters $\left(\mathrm{E}_{\mathrm{OCP}}, \mathrm{E}_{\mathrm{corr}}, \mathrm{i}_{\text {corr }}, \mathrm{R}_{\mathrm{p}}, \mathrm{R}\right)$ and process parameters $(\mathrm{Nb} / \mathrm{Mo}$ ratio, $\mathrm{pH}$ and immersion time (IT)).

\subsection{Open circuit potential monitoring}

Although by the monitoring the values of open circuit potential $\left(\mathrm{E}_{\mathrm{OCP}}\right)$ in time the information about corrosion behavior is minimal, the passivity state can be qualitatively evaluated in the case of 
metallic materials. In Figure 1(a,b,c) are shown the EocP values vs. immersion time (IT), and in Table 1 the EOCP values at the end of monitoring time.

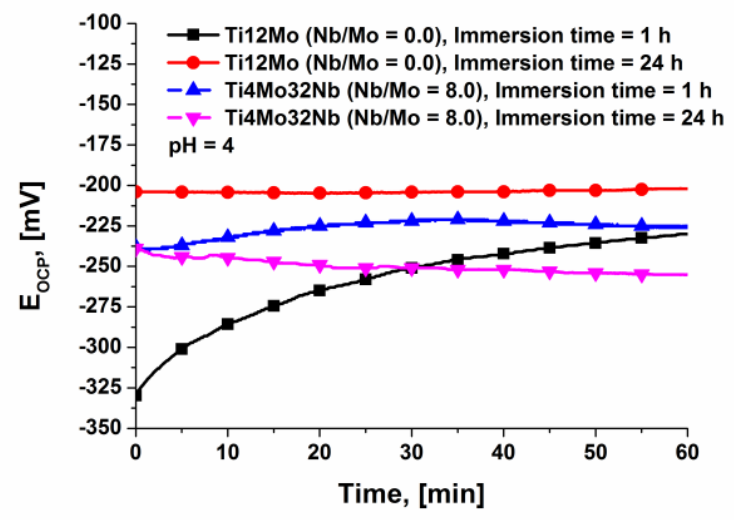

(a)

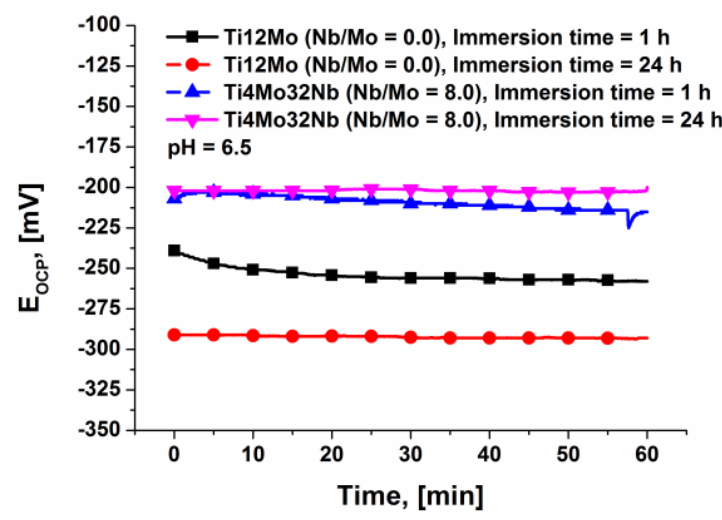

b)

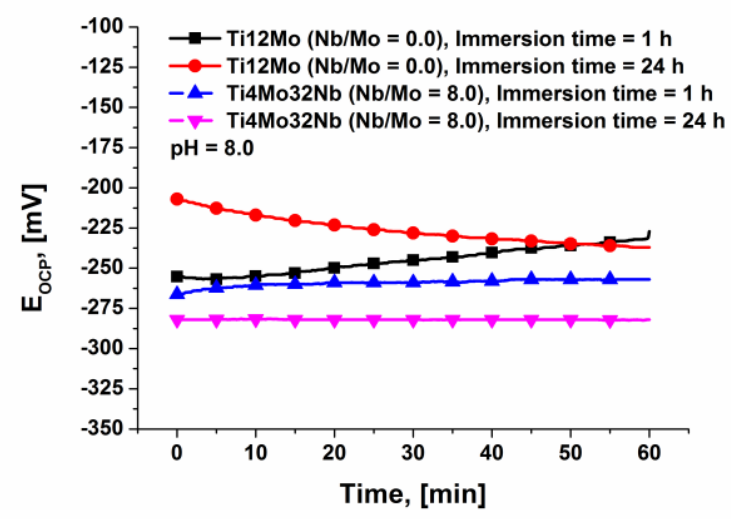

(c)

Figure 1. The evolution in time of the EOCP values in Ringer solutions having different $p \mathrm{H}$ values: a) $p \mathrm{H}=4.0$; b) $p \mathrm{H}=6.5$; c) $p \mathrm{H}=8.0$.

Table 1. The EOCP values of the end of immersion times

\begin{tabular}{|c|c|c|c|c|c|c|}
\hline \multirow{3}{*}{ Alloys (Nb/Mo) } & \multicolumn{6}{|c|}{ pH } \\
\cline { 2 - 7 } & \multicolumn{2}{|c|}{4.0} & \multicolumn{5}{c|}{6.5} & \multicolumn{2}{c|}{8.0} \\
\cline { 2 - 7 } & $1 \mathrm{~h},[\mathrm{~h}]$ \\
\cline { 2 - 7 } & & $24 \mathrm{~h}$ & $1 \mathrm{~h}$ & $24 \mathrm{~h}$ & $1 \mathrm{~h}$ & $24 \mathrm{~h}$ \\
\cline { 2 - 7 } & & \multicolumn{5}{|c|}{ EOCP, [mV] } \\
\hline Ti12Mo (0.0) & -230.0 & -202.0 & -258.0 & -293.0 & -227.0 & -237.0 \\
\hline Ti10Mo8Nb (0.8) & -237.7 & -226.0 & -213.9 & -227.0 & -221.0 & -200.3 \\
\hline Ti8Mo16Nb (2.0) & -233.0 & -270.0 & -225.0 & -237.0 & -258.0 & -264.0 \\
\hline Ti6Mo24Nb (4.0) & -211.0 & -228.2 & -251.0 & -236.7 & -214.0 & -260.0 \\
\hline Ti4Mo32Nb (8.0) & -255.0 & -255.0 & -215.0 & -199.8 & -257.0 & -262.0 \\
\hline
\end{tabular}

From Figure 1(a,b,c) one can observe that the EOCP values are quasi-stable in time even after $24 \mathrm{~h}$ of immersion, with some exception for initial immersion. This evolution indicates that passive films formed on the surface of all Ti alloys, regardless $p \mathrm{H}$ values and immersion times are stable.

\subsection{Analysis of the corrosion behavior using the potentiodynamic polarization}

Potetiodynamic polarization tests allows to estimate the values of some corrosion parameters such as corrosion potential $\left(\mathrm{E}_{\text {corr }}\right)$, corrosion current density ( $\left.\mathrm{i}_{\text {corr }}\right)$ and for corrosion characterized by passivity, breakdown potential $\left(\mathrm{E}_{\mathrm{bd}}\right)$, passive current density $\left(\mathrm{i}_{\mathrm{pas}}\right)$. Figure $2(\mathrm{a}, \mathrm{b}, \mathrm{c})$ shows the characteristic potentiodynamic polarization curves and Table 2 and Table 3 contains the values of 
corrosion parameters $\mathrm{E}_{\text {corr }}$ and $\mathrm{i}_{\text {corr. }}$ The polarization curves have a typical form for passive metallic materials.

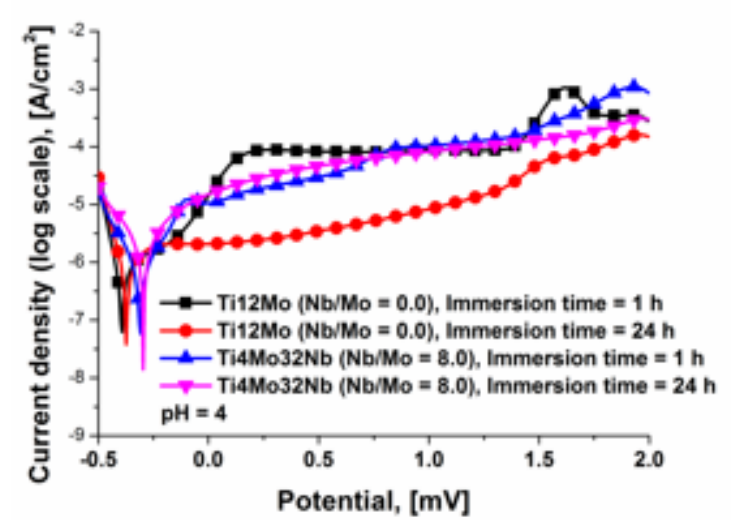

a)

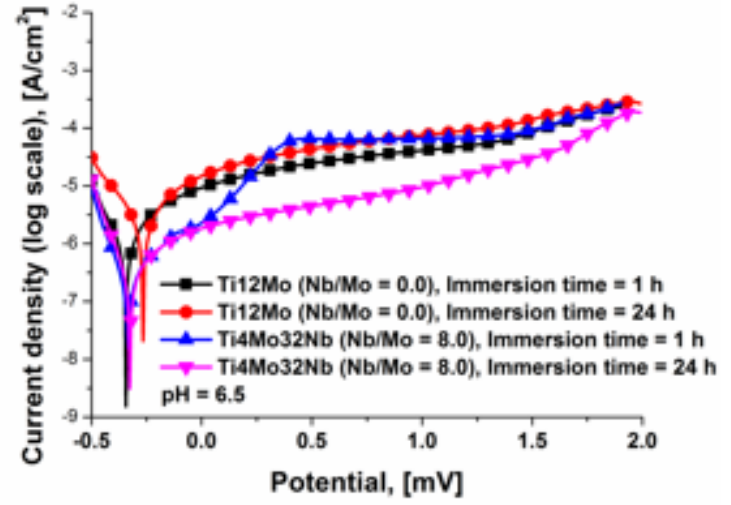

b)

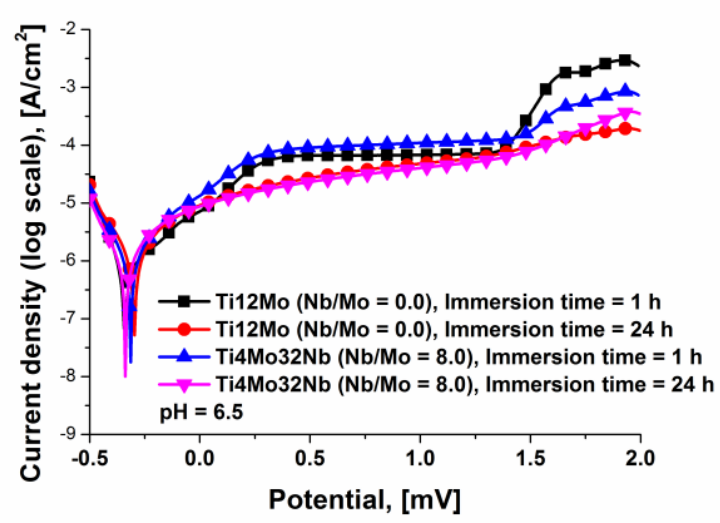

c)

Figure 2. The polarization curves in Ringer solutions having different $p \mathrm{H}$ values: a) $p \mathrm{H}=4.0$; b) $p \mathrm{H}=6.5$; c) $p \mathrm{H}=8.0$.

The shape of polarization curves is characteristic for the titanium-based alloys immersed in simulated body fluids. The curves contain an active-passive transition followed through a passive domain of potential. It is worthy to mention that, after a $24 \mathrm{~h}$ immersion, regardless to alloy and $p \mathrm{H}$, the passivation current density has a slight tendency to increase with the potential. This fact indicates that in time the passive films supports changes concerning structure and thickness. For short immersion time $(1 \mathrm{~h})$, especially for $p \mathrm{H}=8$, a well-defined potential plateau for which passivation current density has a value almost constant can be observed. It can be supposed that the passive films, as immersion time increase, change its features linked to corrosion behavior. Also, for $p \mathrm{H}=8.0$ the passivation current densities have values much closer. The values of $\mathrm{E}_{\text {corr }}$ are less than the values of EOCP that is possible due to potentiodynamic polarization. The corrosion current density for $p \mathrm{H}=4$ and $p \mathrm{H}=6.5$ increased when immersion time has increased, and, inversely, for $p \mathrm{H}=8$ the values of this corrosion parameter has decreased. 
Table 2. The measured values of $\mathrm{E}_{\text {corr }}$ versus experimental parameters used for the potentiodynamic polarization testing

\begin{tabular}{|c|c|c|c|c|c|c|}
\hline \multirow{3}{*}{ Alloys (Nb/Mo) } & \multicolumn{6}{|c|}{ pH } \\
\cline { 2 - 7 } & \multicolumn{7}{|c|}{4.0} & \multicolumn{7}{c|}{6.5} & \multicolumn{2}{c|}{8.0} \\
\cline { 2 - 7 } & \multicolumn{7}{|c|}{ Immersion time, [h] } \\
\cline { 2 - 7 } & $1 \mathrm{~h}$ & $24 \mathrm{~h}$ & $1 \mathrm{~h}$ & $24 \mathrm{~h}$ & $1 \mathrm{~h}$ & $24 \mathrm{~h}$ \\
\cline { 2 - 7 } & \multicolumn{7}{|c|}{ Ecorr, $_{\text {chV] }}$} \\
\hline Ti12Mo (0.0) & -387.7 & -366.3 & -337.3 & -335.1 & -334.0 & -355.5 \\
\hline Ti10Mo8Nb (0.8) & -262.6 & -255.4 & -277.0 & -256.9 & -269.2 & -251.2 \\
\hline Ti8Mo16Nb (2.0) & -375.4 & -360.1 & -408.1 & -349.9 & -315.3 & -349.9 \\
\hline Ti6Mo24Nb (4.0) & -197.7 & -151.2 & -367.7 & -383.6 & -302.0 & -383.6 \\
\hline Ti4Mo32Nb (8.0) & -301.7 & -286.2 & -326.9 & -318.4 & -305.6 & -318.4 \\
\hline
\end{tabular}

Table 3. The measured values of $i_{\text {corr }}$ versus experimental parameters used for the potentiodynamic polarization testing

\begin{tabular}{|c|c|c|c|c|c|c|}
\hline \multirow{5}{*}{ Alloys (Nb/Mo) } & \multicolumn{6}{|c|}{ pH } \\
\hline & \multicolumn{2}{|c|}{4.0} & \multicolumn{2}{|c|}{6.5} & \multicolumn{2}{|c|}{8.0} \\
\hline & \multicolumn{6}{|c|}{ Immersion time, $[\mathrm{h}]$} \\
\hline & $1 \mathrm{~h}$ & $24 \mathrm{~h}$ & $1 \mathrm{~h}$ & $24 \mathrm{~h}$ & $1 \mathrm{~h}$ & $24 \mathrm{~h}$ \\
\hline & \multicolumn{6}{|c|}{$\mathbf{i}_{\text {corr }},\left[\mu \mathrm{A} / \mathrm{cm}^{2}\right]$} \\
\hline Ti12Mo $(0.0)$ & 0.1622 & 0.5997 & 0.4239 & 0.8765 & 0.6511 & 0.4482 \\
\hline Ti10Mo8Nb (0.8) & 0.0980 & 0.5335 & 0.3394 & 0.5316 & 0.2843 & 0.1698 \\
\hline Ti8Mo16Nb (2.0) & 0.0586 & 0.3062 & 0.1920 & 0.2895 & 0.5244 & 0.2895 \\
\hline Ti6Mo24Nb (4.0) & 0.0826 & 0.0679 & 0.1280 & 0.2670 & 0.3833 & 0.1667 \\
\hline Ti4Mo32Nb (8.0) & 0.9124 & 1.3221 & 0.1977 & 0.2566 & 1.1044 & 0.2566 \\
\hline
\end{tabular}

\subsection{Analysis of corrosion behavior using electrochemical impedance spectroscopy}

Electrochemical impedance spectroscopy was performed under the potential conditions in the open circuit. The results were represented as the Bode diagrams, both Impedance module vs. Frequency and Phase angle vs. Frequency. Some Bode diagrams are shown in the Figure 3, and values of electrical quantities from equivalent electric circuit (EEC) are given in Table 4, Table 5, and Table 6. All EIS spectra were fitted using an $\mathrm{R}(\mathrm{QR})$ EEC.

EIS method used in corrosion bring out the structure and properties of passive films in relation with its protective features against corrosion of the substrate. For all investigated alloys, regardless the experimental condition of EIS tests, the spectra were fitted using an equivalent electric circuit identifies by $\mathrm{R}(\mathrm{QR})$. This EEC is characterized by a single time constant, which shows that passive film has a monolayer structure. Having in view the $\mathrm{EEC}(\mathrm{R}(\mathrm{QR}))$, from its electric parameters, the thickness of passive films can be deduced using the following equations [38, 39]:

$$
\begin{gathered}
C_{e f f}=\left((Q \cdot R)^{\frac{1}{n}}\right) / R \\
d=\frac{\varepsilon \cdot \varepsilon_{0}}{C_{e f f}}
\end{gathered}
$$

Using data from Tables 4, 5 and $6, e_{0}=8.8542 \cdot 10^{-14},[\mathrm{~F} / \mathrm{cm}]$, and $e$ from literature, the thickness $d$, [nm] was evaluated for each EIS tests (Tables 4, 5 and 6). 


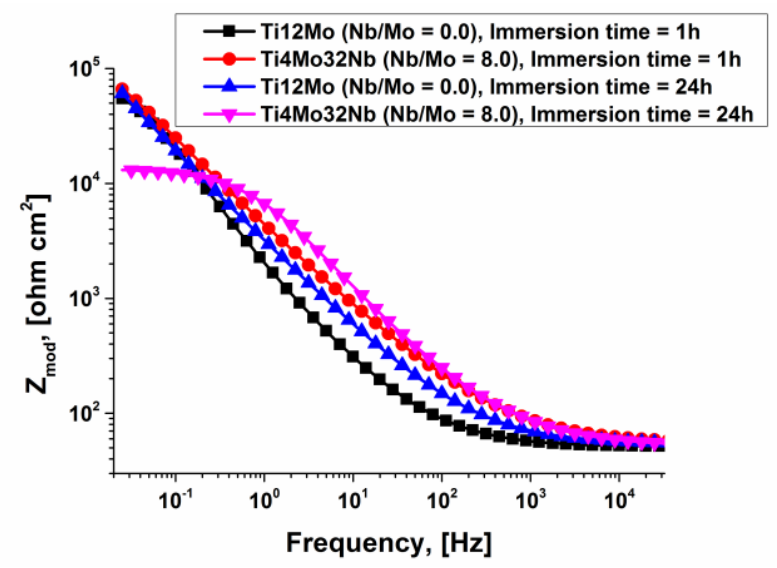

a)

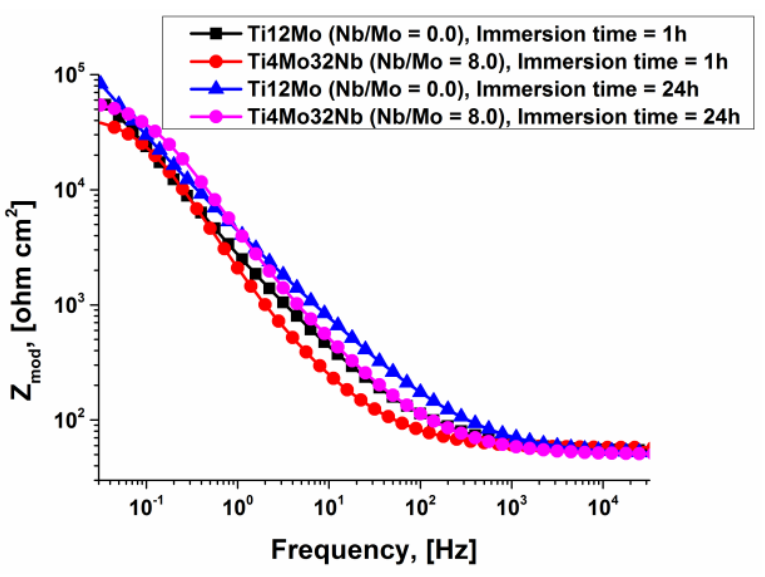

c)

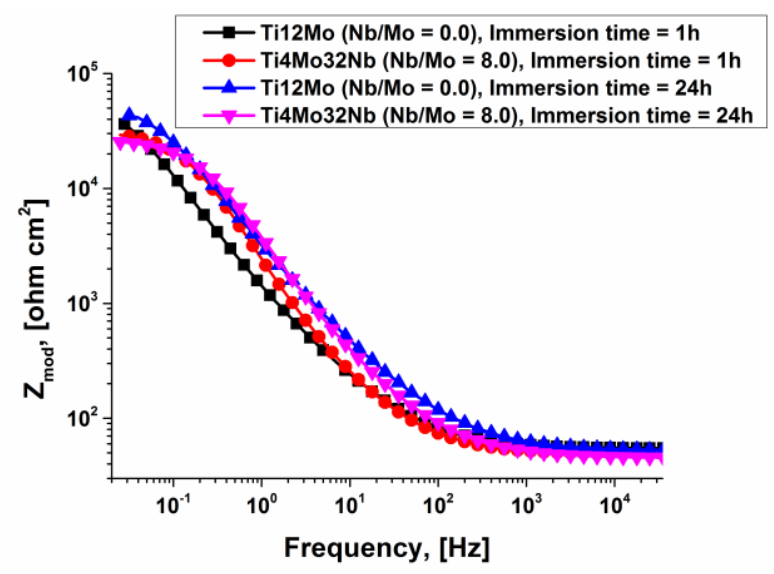

e)

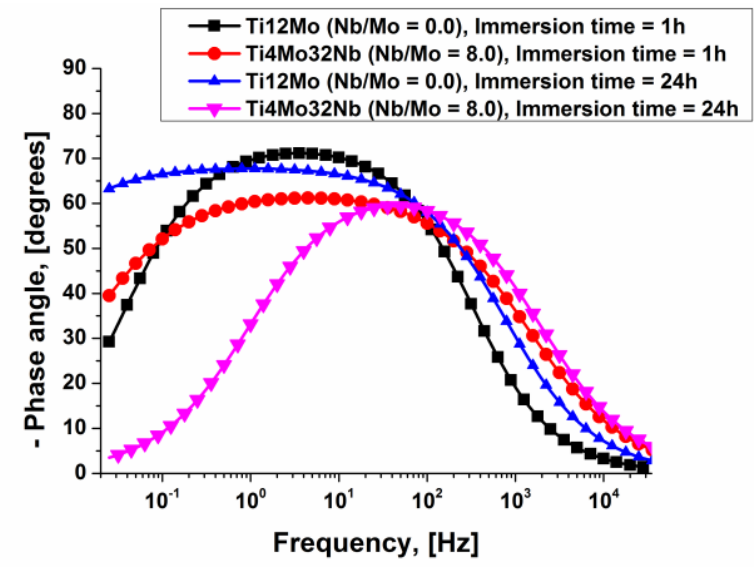

b)

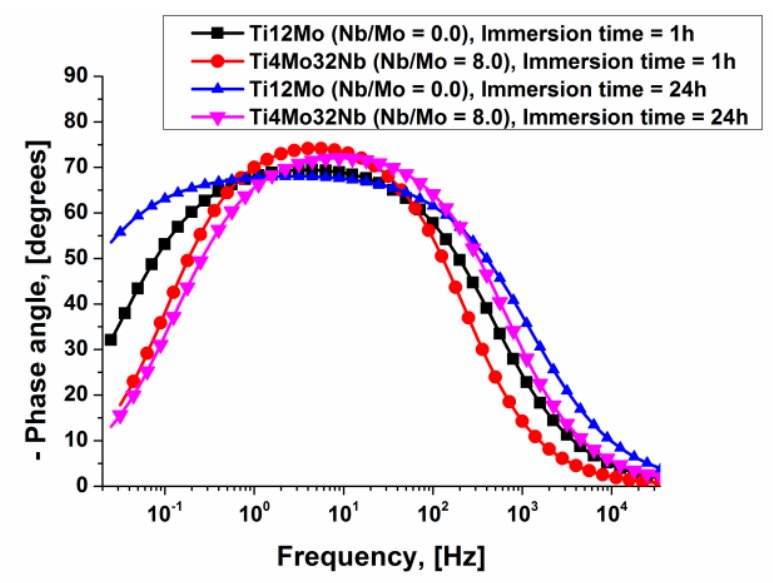

d)

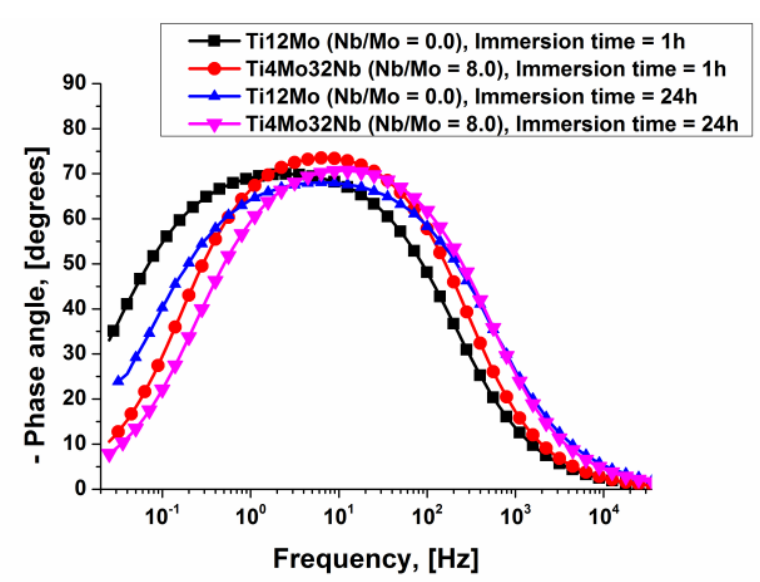

f)

Figure 3. Bode plot of EIS spectra: $\mathrm{Z}_{\bmod }$ vs. Frequency: a) $p \mathrm{H}=4.0$, c) $p \mathrm{H}=6.5$, e) $p \mathrm{H}=8.0$; -Phase angle vs. Frequency: b) $p \mathrm{H}=4.0$, d) $p \mathrm{H}=6.5, \mathrm{f}) p \mathrm{H}=8.0$

From shape of Bode plots and data inside within the tables, a slight difference between electrochemical behavior of investigated alloys can be observed. With the increase of $p \mathrm{H}$, the Bode plots have shapes much more like, and the thickness of the passive films are more uniform. At acidic values of $p \mathrm{H}$ in relation with the chemical composition of alloys and immersion time, the shape of Phase angle vs. Frequency plots are more different. In other words, the more acidic $p \mathrm{H}$, the more 
evident are differences in electrochemical behavior in relation with chemical composition and immersion time.

Table 4. Values of the electrical parameters of EEC for investigated

Ti-based alloys, $p \mathrm{H}=4.0$

\begin{tabular}{|c|c|c|c|c|c|c|}
\hline Alloys (Nb/Mo) & $\begin{array}{c}\mathrm{R}_{\mathrm{s}}, \\
{\left[\mathrm{W} \cdot \mathrm{cm}^{2}\right]}\end{array}$ & $\begin{array}{c}\text { Q, } \\
{\left[\mathrm{mS} \cdot \mathrm{sec}^{\mathrm{n}} / \mathrm{cm}^{2}\right] /} \\
\mathrm{d},[\mathrm{nm}]\end{array}$ & $\mathrm{n}$ & $\begin{array}{c}\mathrm{R}, \\
{\left[\mathrm{kW} \cdot \mathrm{cm}^{2}\right]}\end{array}$ & $\mathrm{c}^{2} / 10^{-2}$ & EEC \\
\hline \multicolumn{7}{|c|}{ after 1 hour of immersion } \\
\hline Ti12Mo (0.0) & 54.10 & $11.64 / 6$ & 0.77 & 88.340 & 0.96 & $\mathrm{R}(\mathrm{QR})$ \\
\hline Ti10Mo8Nb (0.8) & 47.43 & $52.97 / 1$ & 0.85 & 86.640 & 0.40 & $\mathrm{R}(\mathrm{QR})$ \\
\hline Ti8Mo16Nb (2.0) & 57.02 & $37.55 / 2$ & 0.85 & 72.300 & 0.41 & $\mathrm{R}(\mathrm{QR})$ \\
\hline Ti6Mo24Nb (4.0) & 46.56 & $12.92 / 6$ & 0.75 & 73.100 & 0.69 & $\mathrm{R}(\mathrm{QR})$ \\
\hline Ti4Mo32Nb (8.0) & 55.39 & $31.44 / 2$ & 0.87 & 31.380 & 0.63 & $\mathrm{R}(\mathrm{QR})$ \\
\hline \multicolumn{7}{|c|}{ after 24 hours of immersion } \\
\hline Ti12Mo (0.0) & 54.23 & $10.63 / 4$ & 0.76 & 493.300 & 0.29 & $\mathrm{R}(\mathrm{QR})$ \\
\hline Ti10Mo8Nb (0.8) & 49.43 & $39.35 / 1$ & 0.79 & 60.630 & 0.37 & $\mathrm{R}(\mathrm{QR})$ \\
\hline Ti8Mo16Nb (2.0) & 45.95 & $29.72 / 2$ & 0.82 & 31.950 & 0.63 & $\mathrm{R}(\mathrm{QR})$ \\
\hline Ti6Mo24Nb (4.0) & 50.43 & $25.60 / 2$ & 0.78 & 82.450 & 0.43 & $\mathrm{R}(\mathrm{QR})$ \\
\hline Ti4Mo32Nb (8.0) & 52.00 & $26.00 / 3$ & 0.84 & 26.770 & 0.68 & $\mathrm{R}(\mathrm{QR})$ \\
\hline
\end{tabular}

Table 5. Values of the electrical parameters of EEC for investigated

Ti-based alloys, $p \mathrm{H}=6.5$

\begin{tabular}{|c|c|c|c|c|c|c|}
\hline Alloys (Nb/Mo) & $\begin{array}{c}\mathrm{R}_{\mathrm{s}}, \\
{\left[\mathrm{W} \cdot \mathrm{cm}^{2}\right]}\end{array}$ & $\begin{array}{c}\mathrm{Q}, \\
{\left[\mathrm{mS} \cdot \mathrm{sec}^{\mathrm{n}} / \mathrm{cm}^{2}\right] /} \\
\mathrm{d},[\mathrm{nm}]\end{array}$ & $\mathrm{n}$ & $\begin{array}{c}\mathrm{R}, \\
{\left[\mathrm{kW} \cdot \mathrm{cm}^{2}\right]}\end{array}$ & $\mathrm{c}^{2} / 10^{-2}$ & EEC \\
\hline \multicolumn{7}{|c|}{ after 1 hour of immersion } \\
\hline Ti12Mo (0.0) & 52.75 & $12.90 / 6$ & 0.79 & 29.420 & 0.31 & $\mathrm{R}(\mathrm{QR})$ \\
\hline Ti10Mo8Nb (0.8) & 53.81 & $34.19 / 2$ & 0.88 & 89.220 & 0.36 & $\mathrm{R}(\mathrm{QR})$ \\
\hline Ti8Mo16Nb (2.0) & 54.84 & $29.63 / 2$ & 0.84 & 56.300 & 0.39 & $\mathrm{R}(\mathrm{QR})$ \\
\hline Ti6Mo24Nb (4.0) & 54.75 & $22.24 / 3$ & 0.76 & 57.800 & 0.67 & $\mathrm{R}(\mathrm{QR})$ \\
\hline Ti4Mo32Nb (8.0) & 57.43 & $31.91 / 2$ & 0.87 & 45.150 & 0.50 & $\mathrm{R}(\mathrm{QR})$ \\
\hline \multicolumn{7}{|c|}{ after 24 hours of immersion } \\
\hline Ti12Mo (0.0) & 53.10 & $12.00 / 7$ & 0.75 & 46.400 & 0.59 & $\mathrm{R}(\mathrm{QR})$ \\
\hline Ti10Mo8Nb (0.8) & 45.60 & $29.40 / 2$ & 0.80 & 41.890 & 0.45 & $\mathrm{R}(\mathrm{QR})$ \\
\hline Ti8Mo16Nb (2.0) & 59.73 & $19.54 / 3$ & 0.82 & 86.000 & 0.61 & $\mathrm{R}(\mathrm{QR})$ \\
\hline Ti6Mo24Nb (4.0) & 52.87 & $16.54 / 5$ & 0.75 & 52.310 & 0.43 & $\mathrm{R}(\mathrm{QR})$ \\
\hline Ti4Mo32Nb (8.0) & 50.30 & $19.02 / 4$ & 0.84 & 63.270 & 0.55 & $\mathrm{R}(\mathrm{QR})$ \\
\hline
\end{tabular}

Table 4. Values of the electrical parameters of EEC for investigated

Ti-based alloys, $p \mathrm{H}=8.0$

\begin{tabular}{|c|c|c|c|c|c|c|}
\hline Alloys (Nb/Mo) & $\begin{array}{c}\mathrm{R}_{s}, \\
{\left[\mathrm{~W} \cdot \mathrm{cm}^{2}\right]}\end{array}$ & $\begin{array}{c}\mathrm{Q}, \\
{\left[\mathrm{mS} \cdot \mathrm{sec}^{\mathrm{n}} / \mathrm{cm}^{2}\right] /} \\
\mathrm{d}[\mathrm{nm}]\end{array}$ & $\mathrm{n}$ & $\begin{array}{c}\mathrm{R}, \\
{\left[\mathrm{kW} \cdot \mathrm{cm}^{2}\right]}\end{array}$ & $\mathrm{c}^{2} / 10^{-2}$ & EEC \\
\hline \multicolumn{7}{|c|}{ after 1 hour of immersion } \\
\hline Ti12Mo (0.0) & 54.10 & $36.98 / 1$ & 0.82 & 86.100 & 0.96 & $\mathrm{R}(\mathrm{QR})$ \\
\hline Ti10Mo8Nb $(0.8)$ & 47.43 & $24.08 / 2$ & 0.87 & 944.800 & 0.39 & $\mathrm{R}(\mathrm{QR})$ \\
\hline Ti8Mo16Nb (2.0) & 57.02 & $17.90 / 2$ & 0.77 & 577.200 & 0.41 & $\mathrm{R}(\mathrm{QR})$ \\
\hline Ti6Mo24Nb (4.0) & 46.56 & $30.10 / 1$ & 0.84 & 387.100 & 0.69 & $\mathrm{R}(\mathrm{QR})$ \\
\hline Ti4Mo32Nb $(8.0)$ & 55.39 & $30.40 / 1$ & 0.75 & 925.000 & 0.63 & $\mathrm{R}(\mathrm{QR})$ \\
\hline \multicolumn{7}{|c|}{ after 24 hours of immersion } \\
\hline Ti12Mo (0.0) & 54.23 & $29.00 / 2$ & 0.76 & 140.200 & 0.29 & $\mathrm{R}(\mathrm{QR})$ \\
\hline Ti10Mo8Nb $(0.8)$ & 49.43 & $28.69 / 2$ & 0.81 & 53.500 & 0.37 & $\mathrm{R}(\mathrm{QR})$ \\
\hline Ti8Mo16Nb (2.0) & 45.95 & $16.40 / 3$ & 0.75 & 250.900 & 0.63 & $\mathrm{R}(\mathrm{QR})$ \\
\hline Ti6Mo24Nb (4.0) & 50.43 & $27.90 / 2$ & 0.82 & 91.200 & 0.43 & $\mathrm{R}(\mathrm{QR})$ \\
\hline Ti4Mo32Nb (8.0) & 52.00 & $19.87 / 3$ & 0.75 & 134.800 & 0.68 & $\mathrm{R}(\mathrm{QR})$ \\
\hline
\end{tabular}




\section{Conclusions}

As a result of this research on the corrosion behavior of five alloys from Ti-Mo-Nb system in Ringer solution with various values of $p \mathrm{H}$ and for the different immersion times can be formulated the following conclusions.

The more acidic values of $p \mathrm{H}$, the more evident are differences between corrosion behavior of titanium-based alloys depending on their chemical compositions and immersion times. For $p \mathrm{H}$ of 4.0 and a short immersion time the corrosion current densities were the lowers. Increasing immersion time, the values of this corrosion parameter have increased. Inversely, at basic value of $\mathrm{pH}$, the corrosion current densities have slightly decreased when immersion time increased.

Regardless of $p \mathrm{H}$ and immersion times, both lower corrosion current densities and lower thicknesses of passive films were found for alloys which have $\mathrm{Nb} / \mathrm{Mo}$ values within 0.8 and 4.0.

\section{Acknowledgements}

The authors thank Prof. Thierry Gloriant for the support provided in the synthesis of titanium-based materials at ISCR/C-Met-Site INSA Rennes (France).

\section{References}

1. SHI D., Introduction in Biomaterials, Tsinghua University Press, Beijing şi World Scientific Publishing Co. Pte. Ltd., Singapore (2006).

2. GEETHA M., SINGH A.K., ASOKAMANI R., GOGIA A.K., Ti based biomaterials, the ultimate choice for ortopaedic implants, Materials Science, 54 (2009), 397-25.

3. SONG Y., XU D.S., YANG R., LI. D., WU W.T., GUO Z.X., Theoretical study of the effect of alloying elements on the strength and modulus of $\beta$-type bio-titanium alloys, Materials Science Engineering: A, 260 (1999), 269-274.

4.VALERO VIDAL C., IGUAL MUNOZ A., Electrochemical aspects in biomedical alloy characterization: Electrochemical impedance spectroscopy, Biomedical Engineering, Trends in Materials Science, (2011) 283-306.

5. VADIRAJ A., KAMARAJ M., Effect of surface treatments on fretting fatigue damage of biomedical titanium alloys, Tribology International, 40, (2007), 82-88.

6. OKAZAKI Y., GOTOH E., Compararision of metal release from various metallic biomaterials in vitro, Biomaterials, 26, (2005), 11-21.

7. MATSUNO H., YOKOYAMA A., WATARI F., UO M., KAWASAKI T., Biocompatibility and osteogenesis of refractory metal implants Ti, Hf, Nb, Ta, Rh, Biomaterials, 22, (2001), 1253-1262.

8. EISENBARTH E., VELTEN D., MÜLLER M., THULL R., BREME J., Biocompatibility of beta stabilizing elements of titanium alloys, Biomaterials 25 (2004) 5705-5713.

9. LI Y., WONG C., XIONG J., HODGSON P., WEN C., Cytotoxicity of titanium and titanium alloying elements, Journal of Dental Research 89 (5), (2010) 493-497.

10. HO W.F., JU C.P., CHERN LIN J.H., Structure and proprieties of cast Ti-Mo alloys, Biomaterials, 20, (1999), 2115-2122.

11. TRENTANi L., PElillo F., PAVESi F.C., CECIliAni L., CETTA G., FORlinO A., Evaluation of the TiMo12Zr6Fe2 alloy for orthopedic implants: in vitro biocompatibility study by using primary human fibroblasts and osteoblasts, Biomaterials, 23, (2002), 2863-2869.

12. GORDIN D.M., GLORIANT T., TEXIER G., THIBON I., ANSEL D., DUVAL J.I., NAGEL M.D., Development of a $\beta$-type Ti-12Mo-5Ta alloy for biomedical applications: cyto-compatibility and metallurgical aspects, Journal of Materials Science : Materials in Medicine, 15, (2004) 885-891.

13. NAG S., BANERJEE R., FRASER H.L., Microstructural evolution and strengthening mechanisms in Ti-Nb-Zr-Ta, Ti-Mo-Zr-Fe and Ti-15Mo biocompatible alloys, Materials Science and Engineering, C25, (2005), 357-362.

14. POLMEAR I.J., Light Alloys From Traditional Alloys to Nanocrystals, $4^{\text {th }}$ ed. Elsevier, pp.301 (2006). 
15. LU J.W., ZHAO Y.Q., GE P., NIU H.Z., Microstructure and beta grain growth behavior of Ti-Mo alloys solution treated, Materials Characterization, 84, (2013), 105-111.

16. MARECI D., CHELARIU R., GORDIN D.M., UNGUREANU G., GLORIANT T., Comparative corrosion study of Ti-Ta alloys for dental application, Acta Biomaterialia, 5, (2009), 3625-3639.

17. KARTEGA M., RAMAN V., RAJENDRAM N., Influence of potential on the electrochemical behavior of $\beta$ titanium alloys in Hank's solution, Acta Biomaterialia, 3, (2007), 1019-1023.

18. MARECI D., CHELARIU R., GORDIN D.M., ROMAȘ M., SUTIMAN D., GLORIANT T., The corrosion behaviour of Ti20Mo in non-pasteurized orange juice, Proceedings of the 12th World Conference on Titanium, vol. III, (2012), 2081-2085.

19. GUO W.Y., SUN J., WU J.S., Electrochemical and XPS studies of corrosion behavior of Ti-23Nb0.7Ta-2Zr-O alloy in Ringer s solution, Materials Chemistry and Physics, 113, 2009, 816-820.

20. GALLIANO F., GALVANETTO E., MISCHELER S., LANDOLT D., Tribocorrosion behavior of plasma nitrited Ti-6Al-4V alloy in neutral NaCl solution, Surface and Coatings Technology, 204, (2001), 2928-2932.

21. MARECI D., CHELARIU R., GORDIN D.M, ROMAȘ M., SUTIMAN D., GLORIANT T., Effect of Mo content on electrochemical behaviour of TiMo alloys for dental applications, Materials and Corrosion, 10, (2010), 829-837.

22. OLIVEIRA N.T.C., GUASTALDI A.C., Electrochemical behavior of Ti-Mo alloys applied as biomaterial, Corrosion Science, 50, (2008), 938-945.

23. OLIVEIRA N.T.C., GUASTALDI A.C., Electrochemical stability and corrosion resistance of TiMo alloys for medical applications, Acta Biomaterialia, 5, (2009), 399-405.

24. OLIVEIRA N.T.C., ALEIXO G., CARAM R., GUASTALDI A.C., Development of Ti-Mo alloys for biomedical applications: Microstructure and electrochemical characterization, Material Science and Engineering A, 452-453, (2007), 727-731.

25. ZHOU Y.L., LUO D.M., Microstructures and mechanical properties of Ti-Mo alloys cold-rolled and heat treated, Materials Characterization, 62, (2011), 931-937.

26. ZHAO C., ZHANG X., CAO P., Mechanical and electrochemical characterization of Ti-12Mo-5Zr alloy for medical application, J. Alloys and Comp, 32, (2011), 8235-8238.

27. D. SRI MAHA VISHNU, J. SURE, Y. LIU, R. VASANT KUMAR, C. SCHWANDT, Electrochemical synthesis of porous Ti-Nb alloys for biomedical applications, Mater. Sci. Eng. C 96 (2019) 466-478

28. R. KARRE, B.K. KODLI, A. RAJENDRAN, N. J, D.K. PATTANAYAK, K. AMEYAMA, S.R. DEY, Comparative study on Ti-Nb binary alloys fabricated through spark plasma sintering and conventional P/M routes for biomedical application, Mater. Sci. Eng. C 94 (2019) 619-627.

29. M. DINU, S. FRANCHI, V. PRUNA, C.M. COTRUT, V. SECCHI, M. SANTI, I. TITORENCU, C. BATTOCCHIO, G. IUCCI, A. VLADESCU, Ti-Nb-Zr system and its surface biofunctionalization for biomedical applications, in: F.H. Froes, M. Qian (Eds.), Titanium in Medical and Dental Applications, Woodhead Publishing, 2018, pp. 175-200.

30. M. KAUR, K. SINGH, Review on titanium and titanium-based alloys as biomaterials for orthopaedic applications, Mater. Sci. Eng. C 102 (2019)

31. A. MADHAN KUMAR, A.Y. ADESINA, M.A. HUSSEIN, S. RAMAKRISHNA, N. ALAQEELI, S. AKHTAR, S. SARAVANAN, PEDOT/FHA nanocomposite coatings on newly developed $\mathrm{Ti}-\mathrm{Nb}-\mathrm{Zr}$ implants: biocompatibility and surface protection against corrosion and bacterial infections, Mater. Sci. Eng. C 98 (2019) 482-495.

32. H. HU, L. ZHANG, Z. HE, Y. JIANG, J. TAN, Microstructure evolution, mechanical properties, and enhanced bioactivity of Ti-13Nb-13Zr based calcium pyrophosphate composites for biomedical applications, Mater. Sci. Eng. C 98 (2019) 279-287.

33. S. OZAN, J. LIN, Y.LI, Y. ZHANG, K. MUNIR, H. JIANG, C. WEN, Deformation mechanism and mechanical properties of a thermomechanically processed $\beta \mathrm{Ti}-28 \mathrm{Nb}-35.4 \mathrm{Zr}$ alloy, J. Mech. Behav. Biomed. Mater. 78 (2018) 224-234. 
34. J.C. WANG, Y.J. LIU, P. QIN, S.X. LIANG, T.B. SERCOMBE, L.C. ZHANG, Selective laser melting of $\mathrm{Ti}-35 \mathrm{Nb}$ composite from elemental powder mixture: microstructure, mechanical behavior and corrosion behavior, Mater. Sci. Eng. A 760 (2019) 214-224.

35. C.D. RABADIA, Y.J. LIU, G.H. CAO, Y.H. LI, C.W. ZHANG, T.B. SERCOMBE, H. SUN, L.C. ZHANG, High-strength $\beta$ stabilized Ti-Nb-Fe-Cr alloys with large plasticity, Mater. Sci. Eng. A 732 (2018) 368-377.

36. J. WANG, Q. LI, C. XIONG, Y. LI, B. SUN, Effect of Zr on the martensitic transformation and the shape memory effect in Ti-Zr-Nb-Ta high-temperature shape memory alloys, J. Alloys Compd. 737 (2018) 672-677.

37. R. CHELARIU, G. BOLAT, J. IZQUIERDO, D. MARECI, D.M. GORDIN, T. GLORIANT, R.M. SOUTO, Metastable beta Ti-Nb-Mo alloys with improved corrosion resistance in saline solution, Electrochim. Acta 137 (2014) 280-289

38. M. N. KAKAEI, J. NESHATI, A. R. REZAIEROD, On the Extraction of the Effective Capacitance from Constant Phase Element Parameters, Protection of Metals and Physical Chemistry of Surfaces, 2018; 54(3):548-556.

39.B. HIRSCHORN, M.E. ORAZEM, B. TRIBOLLET, V. VIVIER, I. FRATEUR, M. MUSIANI, Determination of effective capacitance and film thickness from constant-phase-element parameters, Electrochim. Acta, 2010; 55:6218-6227.

Manuscript received: 27.05 .2020 